\title{
Molecular analysis of milk yield and components associated with some genetic markers in dairy cattle.
}

\author{
Hamada, M. ${ }^{1}$, Khalil, M.H. ${ }^{2}$, Iraqi, M.M. ${ }^{2}$, Zahed, S. ${ }^{1}$ \\ ${ }^{1}$ Animal Production Research Institute, Dokki, Giza, Egypt. \\ ${ }^{2}$ Department of Animal Production, Faculty of Agriculture at Moshtohor, Benha University, Egypt.
}

Corresponding author: maher.khalil@ fagr.bu.edu.eg

\begin{abstract}
Prolactin and Lactoferrine genes related with milk yield and milk components were analyzed for 180 milking cows. Genotyping for these two genes were investigated to detect their associations with yields of milk, fat and protein and age at first calving (AFC). About 38 local cows from Serw farm (Baladi) in Damietta governorate, 62 Friesian cows from Sakha farm and 80 from El Karada farm in Kafr El-Sheikh. Blood samples were collected from all cows in EDTA tubes and salting out method was used to extract DNA from these blood samples. PCR RFLP method was used to get single nucleotide polymorphism (SNP) by PCR technique. Three enzymes were used to restrict DNA product (HINF1 for lactoferrin gene, MRON1 and SML1 restriction enzymes for prolactin gene).

There were significant differences among three genotypes (AA, $\mathrm{AB}$ and $\mathrm{BB}$ ) detected by restriction enzyme HINF1 in Frisian cattle for milk, fat, protein yield traits but not significance for AFC trait. The genotype AB was the best one for milk, fat and protein yields. In local cattle at Serw farm, there was no significance differences among three genotypes for milk, fat and protein yield, but for age at first calving there were significance differences. The genotypes from restriction enzyme MRON1 were two genotypes (CD and DD) for El-Qarada herd. There were significant differences between the two genotypes in Frisian herd for milk, fat, protein yields, but significance for AFC trait. In Serw herd, there were not significant differences among the three genotypes for milk, fat and protein yields, but AFC was significance. Genotypes from restriction enzyme SML1 were GG, GT and TT. There were significance differences among three genotypes in Friesian herd for milk, fat and protein yields, while in AFC there were non-significance differences. In Sero herd, differences in genotyping among four traits were not significant.
\end{abstract}

Key words: Dairy cattle, Molecular analysis, PCR RFLP, Milk yield and components, Prolactin and Lactoferrine genes. 
